Studia Slavica Savariensia 2018. 1-2. 10-23

DOI: $10.17668 /$ SSS.2018.1-2.10

Сагинтай Бердагулова

(Астана, Казахстан)

\title{
У ИРТЫШСКИХ ИСТОКОВ
}

\begin{abstract}
The article dedicated to the history of the Great Russian writer Feodor Dostoyevsky staying in Kazakhstan at 1854-1859 years. There are events of five years of the Dostoyevsky life in Kazakh Steppe, his creative revival, the Turkic origins of the Dostoyevsky ancestry and an analysis of historical data in this paper. The article author has used many original sources.
\end{abstract}

Keywords: Steppe, writer, soldier, Turkic

История Казахской степи богата событиями и именами. Огромные просторы в центре Евразии стали ареной исторических переплетений явлений, фактов, судеб. Здесь побывали многие выдающиеся ученые, исследователи, поэты, писатели.

В новое время одним из первых здесь побывал русский классик Александр Сергеевич Пушкин. Он посетил западный город Уральск в 1833 году, когда собирал материал к своей книге о восстании Пугачева. Чуть позже в Казахстане оказался политический ссыльный, польский дворянин из Белоруссии Адольф Янушкевич. В середине девятнадцатого столетия такая же судьба занесла сюда Тараса Шевченко, ставшего классиком украинской литературы.

Русский философ и всемирно известный романист Лев Толстой, принимавший неподалеку от казахских степей лечение кумысом, летом 1862 года три дня пробыл также в городе Уральске.

Особую страницу истории нашей страны, ее культуры и литературы занимает Федор Михайлович Достоевский. Русский писатель с древними тюркскими корнями, имя которого известно всему читающему человечеству, пожалуй, дольше всех, хоть и не по своей воле, прожил на казахской земле.

В 1854 году ссыльный русский литератор Ф.М. Достоевский, окончивший срок каторжных работ на территории западной Сибири, в Омском остроге (тюрьме), был зачислен рядовым в Седьмой сибирский линейный батальон, стоявший в Семипалатинске. Сейчас этот город на востоке Казахстана называется Семей.

Как написал позже местный журналист Габит Зулхаров, «будущий писатель Ф.М. Достоевский (1821-1881) за участие в молодежном тайном обществе, выступавшем за реформы российского самодержавного строя, 
был приговорен, по «делу Петрашевского», к смертной казни (1849 г.), измененного позже на длительные каторжные работы, где он и побывал в солдатах. Правда и то, что последние пять лет репрессий и преследований Достоевский провел на солдатской службе в Семей» (Перевод с казахского языка - С.Б.) (ЗУЛХАРОВ: 39\&ID=5097)

Но перед отправкой туда, после выхода из заключения он и его товарищ по несчастью Дуров провели почти месяц в городе Омск, в доме Константина Ивановича Иванова. Это был однокашник Ф.М. Достоевского по инженерному корпусу, который служил тогда в Омске адъютантом генерал-майора Бориславского - начальника инженеров Отдельного сибирского корпуса (ГРОМЫКО 1985: 56-57) Дорога в город Семипалатинск началась для Ф. Достоевского со знакомства в этом доме с одним из первых казахских просветителей и общественных деятелей, прямым потомком Чингисхана, внуком хана Абылая, Шоканом Уалихановым (ГРОМЫКО 1985: 60) (далее в тексте Чокан Валиханов, по написанию того времени).

После, весной того же 1854 года на возу с пеньковым канатом Федор Достоевский выехал в воинские части. Есть образное описание этого пути у П. Косенко: «Из Омска в Семипалатинск по правому берегу Иртыша через станицы...едет счастливый человек... Через много лет, уже на исходе жизни, вспомнив дни этого санного пути, он назовет их самыми счастливыми днями своей жизни» (КОСЕНКО 1971: 4)

По прибытии в город, Федор Михайлович поделится первыми впечатлениями с братом Михаилом, называя в письме Семипалатинск полугородом-полудеревней, где всего лишь один магазин, одна аптека, одно начальное училище.

В то же время, чуть позже, 27 марта 1854 года, он пишет уже бодро и с интересом:

«Климат здесь довольно здоров. Здесь уже начало киргизской степи...Степь открытая. Лето длинное и горячее, зима короче, чем в Тобольске и в Омске, но суровая. Растительности решительно никакой, ни деревца - чистая степь. ...бор на сотни верст...Дичи тьма. Порядочно торгуют...Когда-нибудь я напишу тебе о Семипалатинске подробнее. Это стоит того» (ДОСТОЕВСКИЙ 1985: 178-179).

В биографии Федора Михайловича Достоевского Семипалатинск был городом перемен - он ждал амнистии, верил, что скоро сможет вернуться в Россию. С описания Семипалатинска начинается одно из самых известных его произведений «Записки из Мертвого дома»: «В отдаленных краях Сибири, среди степей, гор или непроходимых лесов, попадаются изредка маленькие города...».

В его повести «Дядюшкин сон», события которой разворачиваются в этом же городке, дана похожая короткая характеристика.

Проживая в Семипалатинске, Ф. Достоевский поменял четыре адреса. Около месяца он жил в казармах с солдатами. Но потом по ходатайству 
уже упомянутого однокашника К. Иванова ему, «солдату-петрашевцу, разрешили жить в Семипалатинске не в казарме, а отдельно, в частном доме.... Это чрезвычайно важное для Достоевского ходатайство, давшее ему возможность писать, было удовлетворено 20 ноября 1854 года» (ГРОМЫКО 1985: 62).

И он поселился в доме на окраине города: «Хата Достоевского находилась в самом безотрадном месте. Кругом пустырь, сыпучий песок, ни куста, ни дерева. Изба была бревенчатая, древняя, скривившаяся на один бок, без фундамента, вросшая в землю, и без единого окна наружу, ради опасения от грабителей и воров... У Достоевского была одна комната, довольно большая, но чрезвычайно низкая; в ней царствовал всегда полумрак. Бревенчатые стены были смазаны глиной и когда-то выбелены; вдоль двух стен шла широкая скамья. На стенах там и сям лубочные картинки, засаленные и засиженные мухами. У входа налево от дверей большая русская печь. За нею помещалась постель Федора Михайловича, столик и, вместо комода, простой дощатый ящик. Все это спальное помещение отделялось от прочего ситцевою перегородкою. За перегородкой в главном помещении стоял стол, маленькое в раме зеркальце. На окнах красовались горшки с геранью, и были занавески, вероятно когда-то красные. Вся комната была закопчена и так темна, что вечером с сальною свечою - стеариновые тогда были большою роскошью, а освещения керосином еще не существовало...» (ГРОМЫКО 1985: 62).

Но именно в этом городке, здесь, на казахской земле, Ф. Достоевский проведет пять лет своей жизни, о которых впоследствии скажет: «По крайней мере, жил, хоть страдал, да жил!» Начинался новый этап жизни Достоевского - ссылка и солдатская служба.

Семипалатинский период для писателя был временем тяжелой солдатчины: ежедневная муштра, тяготы службы. Осенью 1854 года в письме брату Андрею он писал: «Все лето я был так занят, что едва находил время спать (ДОСТОЕВСКИЙ 1985:182).

Позже, здесь же, Семипалатинске, Федор Ивановича повысили в воинском звании. Сначала до унтер-офицера, а потом - и до прапорщика. Так, приказ о производстве его в прапорщики в октябре 1856 года прислал Ф. Достоевскому его прежний семипалатинский знакомец Иванов (ГРОМЫКО 1985: 63).

Еще одну хорошую новость он получил также находясь в Казахстане ему был возвращен дворянский титул. В мае 1857 года Ф.М. Достоевский «получил еще монаршею милость: возвращение прежнего потомственного дворянства (ДОСТОЕВСКИЙ 1985: 286).

Оба эти исторических факта: присвоение воинского звания и возврат наследственного титула были знаком дальнейшего восстановления гражданских прав Федора Достоевского, возвращения его статуса. Более 
того, стали прологом к началу нового, важнейшего этапа в биографии Ф.М. Достоевского.

Более того, это также было время медленного и трудного возвращения не только к жизни, но и, после многих лет вынужденного молчания, к литературе.

«Выйдя из моей грустной каторги, я со счастьем и надеждой приехал сюда. Я походил на больного, который начинает выздоравливать после долгой болезни и, быв у смерти, еще сильнее чувствует наслаждение жить в первые дни выздоровления. Надежды было у меня много. Я хотел жить...» ... (ДОСТОЕВСКИЙ 1985: 201).

Сам факт активной переписки Федора Михайловича, жадные поиски общения, жизни на воле, весьма показательны для свободной, хоть и относительно свободной, жизни бывшего арестанта. За время пребывания здесь, за пять лет, он написал 60 писем, или по одному письму в месяц в среднем. По крайней мере, в полном собрании сочинений Ф.М. Достоевского они значатся с 91-го по 151-е (ДОСТОЕВСКИЙ 1985: 178330). И это несмотря на тогдашние возможности доставки корреспонденции, которые подметил и сам писатель, «почта из Петербурга в Семипалатинск ходит обыкновенно 22 или 25 дней (между этими числами) (ДОСТОЕВСКИЙ 1985: 313).

Годы, проведенные в Казахстане, - это время возвращения Достоевского к литературному труду. Самое главное - он снова мог заниматься своим любимым делом, писать: «На душе моей ясно. Вся будущность моя, и все, что я сделаю, у меня, как перед глазами. Я доволен своей жизнью» (ДОСТОЕВСКИЙ 1985: 301).

Через два года пребывания в казахском Семипалатинске еще более заметны оживление и надежды: «Теперь не так прежде, столько обделанного, столько обдуманного и такая энергия к письму!», писал Федор Михайлович в одном из своих посланий (ДОСТОЕВСКИЙ 1985: 214).

Но работа все же шла нелегко, много времени отнимала солдатская служба. Ф. Достоевский ненавидел муштру и смотры еще в Военноинженерном училище. Ему опять пришлось надеть форменную одежду. «Солдатство не шутка, ... солдатская жизнь со всеми ее обязанностями солдата не совсем-то легка для человека с таким здоровьем и с такой отвычкой или, лучше сказать, с таким полным ничегонезнанием в подобных занятиях... Я не ропщу; это мой крест...».

Все это было для писателя тем более невыносимо, т.к. он «по складу его ума и по силе убеждений, не любил подчиняться какому бы там ни было авторитету... (ВОЛГИН 1991:578).

Но, в Семипалатинске Федор Михайлович не только проходил «суровую школу невзгод». Именно здесь, в Казахстане, 34-летний писатель познакомился со своей будущей супругой М.И. Исаевой. Впервые в жизни он любил и был любим. И это очень важный феномен. 
Известно, что творчество и жизнь Ф.М. Достоевского, как писателя мировой величины, изучены весьма подробно. И тут все исследователи сходятся во мнении, что за ним никогда не было замечено свойственное молодости увлечения барышнями. Современники Достоевского, а позже, и его вторая жена Анна Григорьевна объясняли это тем что, «он слишком рано начал жить умственной жизнью. Творчество всецело поглотило его, a потому личная жизнь отошла на второй план. Затем он всеми помыслами ушел в политическую историю, за которую так жестоко поплатился» (ВОЛГИН 1991: 534). Следовательно, это знакомство и последующая женитьба стали свидетельством мощных перемен, охвативших молодого человека.

В письме к брату Михаилу 9 марта 1857 года влюбленный Федор Достоевский не только выказывает психологическое оздоровление, но и приходит к следующему выводу:

«Удивительное дело, из тяжкого несчастья и опыта я вынес необыкновенную бодрость и самоуверенность (ДОСТОЕВСКИЙ 1985: 276).

Примечательно, что во второй половине лета Ф.М. Достоевский получил официальное разрешение на поездку в Змеиногорск, куда переехала Исаева. Слуга Врангеля финн по имени Адам сшил Ф. Достоевскому «партикулярное» платье - первую штатскую одежду, которую писатель, спустя шести лет заключения и воинской службы, надел в Семипалатинске (КОСЕНКО 1971: 55).

О том, что он был вполне доволен переменами в личной жизни, Федор Михайлович пишет после свадьбы в письме от 31 августа 1857 года: «Живем мы понемногу и покамест не имеем причин жаловаться на судьбу (КОСЕНКО 1971: 286).

Именно здесь, на Иртыше познакомился и подружился Ф. Достоевский с интересными людьми. Среди многих, самыми теплыми оказались отношения с двумя молодыми людьми. Это были Александр Врангель, прокурор области, и Шокан Уалиханов, с которым он сдружился еще в Омске.

Наиболее частым было общение с бароном Врангелем. Оно оказалось очень полезным и для знакомства Достоевского с местными жителями, казахами. «По своим служебным обязанностям Врангель много ездил по степи. Он рассказывал молодому Достоевскому о жизни аулов, которой тот очень интересовался (даже Коран начал читать, чтобы понять мировоззрение мусульман), но пока мало знал» (КОСЕНКО 1971: 39).

Действительно, как следует из переписки, в первом, сразу после каторги, письме Ф.М. Достоевского брату Михаилу от 22 февраля 1854 г., зная, что ему ехать дальше, в Семипалатинск, на территорию Казахстана, он просит прислать ему книги и начинает список с Корана, посвящая ему отдельное предложение: «Пришли мне Коран» (ДОСТОЕВСКИЙ 1985: 172). 
Новый друг Ф. Достоевского Александр Егорович Врангель рассказывал писателю о казахских обычаях, с которыми уже успел познакомиться сам, говорил, что «к русским властям казахи испытывают просто отвращение», и он приводил отрицательные примеры. Так, начальника губернского правления «откровеннейшего» взяточника Малосапожкова сам Ф.М. Достоевский прозвал «жареным скорпионом» (КОСЕНКО 1971: 40).

Как писатель и гуманист, он очень переживал, чувствуя ответственность за эту порочную практику. Он говорил: «Разумеется, жареные скорпионы - это не русский народ, но страшно подумать, что коренные жители степи по ним могут судить о нашем народе» (КОСЕНКО 1971: 40).

Тягостную картину дополнял волюнтаризм самого главы Степного края. Генерал-губернатор Гасфорт додумался до того, что разработал проект новой религии для степняков. Мусульманство его не устраивало, православие же плохо вязалось с некоторыми обычаями Степи, например, с многоженством. Гасфорт задумал приспособить к местным условиям иудаизм (КОСЕНКО 1971: 48). Но затея эта была столь чудовищной, что даже царь был шокирован и отклонил проект.

Не только тонкий психологизм, но и человеколюбие Ф. Достоевского придавали его собственным поискам, размышлениям о природе явлений и о судьбах простых людей столь искреннюю глубину и сострадание.

Образование, воспитание, происхождение Федора Михайловича Достоевского сформировали в нем глубокое убеждение в особенности русского характера, его глубоком отличии от европейской культуры.

Он был уверен, что реформа, которую царь Петр 1, провел на Руси, «слишком дорого стоила: она разъединила нас с народом. С самого начала народ от нее отказался» (ГУРАЛЬНИК 1972: 435).

Потому что «Петр Великий, чтоб подавить аристократию бояр, ввел 14 классов, которые ...в себе все вмещают, а особливости и своеобразности русского народа и сил его мало признают, а потому и России вне Европы не признают, пишет Ф.М. Достоевский в 1880г. в письме к И.С. Аксакову. (ГУРАЛЬНИК 1972: 438).

Его «цивилизационные» убеждения были общеизвестны. Хотя он и считался «бессознательным славянофилом» (ГУРАЛЬНИК 1972: 434). При этом, не найдется ни одной более или менее солидной работы о Ф. Достоевском, в которой не отмечалась бы связь мировоззрения писателя с той или иной стороной славянофильской доктрины (ГУРАЛЬНИК 1972: 430).

И переоценка ценностей, которая сделала Ф.М. Достоевского в известном смысле союзником славянофилов, одним из адептов почвенничества..., произошла в сознании писателя... во время сибирской ссылки (ГУРАЛЬНИК 1972: 433). Континентальное мировоззрение 
писателя, как жителя другого, отличного от европейского, мира, окончательно оформилось именно в казахской степи.

И как верно подмечено одним из исследователей: «С Достоевским случилось то же, что совершается вот уже более столетия со всеми нашими крупными писателями; все они начинали с того, что увлекались чужим, и все потом возвратились к своему... Так было с Карамзиным, Грибоедовым, Пушкин, Гоголем (ГУРАЛЬНИК 1972: 440-441).

Что же касается, семипалатинского друга Ф. Достоевского А.Е. Врангеля, то он с гордостью рассказывал, что сумел завоевать в аулах уважение и получил от казахов почтительное прозвище карасакала чернобородого (КОСЕНКО 1971: 40).

Ф.М. Достоевскому были очень интересны описания знатока, он мечтал о времени, когда сам сможет выезжать в степь. Предполагали, что летом этого можно будет добиться. Пока же друзья бывали у степняков, осевших в городе: у купца Буката Аупаева, хозяина богатого, прочно построенного дома в Татарской слободе, у торгового представителя ташкентского бека Рахимбая Атанбаева (были у него даже на свадьбе его дочери). Много интересного о жизни Степи рассказывал и купец Степанов, у которого А. Е. Врангель снимал квартиру. Мать Степанова была казашка, она жила в доме сына. К ним часто наведывались гости из дальних аулов. (КОСЕНКО 1971: 40).

Впоследствии Федор Достоевский, научившись скакать верхом, стал выезжать в степь. Его очень интересовала жизнь людей в степном краю. С Врангелем они часто бывали на летовках, заводили разговоры с кочевниками. Скоро среди казахов у них завелись и друзья. Они несколько раз гостили в юртах богатых степняков Мендыбая и Тенибая... Гостей же удивляло, как знали их хозяева о событиях на самых дальних кочевьях. К удивлению русских, в разговоре принимали свободное участие и молодые жены хозяев. (КОСЕНКО 1971: 53).

Примечательно, что, несмотря на дружбу этих двух молодых людей, у них было разное восприятие жизни степняков. Один из них был сторонний наблюдатель, пришелец, другой - понимал местную жизнь изнутри. Как-то на замечание немецкого барона Врангеля, что этот народ (казахи - БСК) самой природой обречен оставаться на невысокой степени развития, Ф.М. Достоевский резко возразил... «Что же касается до народа, с которым мы теперь знакомимся, то одного такого человека, как омский офицер Валиханов, достаточно, чтобы доказать, что народ этот очень даже способен к самой высокой степени развития.» (КОСЕНКО 1971: 53-54).

Как раз вскоре в Семипалатинск в составе свиты генерал-губернатора (с.61) приехал и сам Валиханов. Он провел на даче Врангеля, где гостил Федор Достоевский, несколько дней.

Барона Врангеля, который только-только познакомился молодым представителем степной аристократии, поразили образованность Чокана 
Валиханова, спокойное изящество его манер, и, главное, сильный и своеобразный ум. (КОСЕНКО 1971: 54).

Ч. Валиханов гостил в Казаковом саду как раз перед его поездкой, опасной поездкой в Ташкент и Коканд.

Несколько раз Ф.М. Достоевский встречался с ним в Семипалатинске. Русский писатель оценил высокие дарования своего нового друга: «...Не великая ли цель, не святое ли дело быть чуть ли не первым из своих, который бы растолковал в России, что такое Степь, ее значение и Ваш народ относительно России, и в то же время служить своей родине просвещенным ходатайством за нее у русских (ДОСТОЕВСКИЙ 1985: 249).

Общение двух великих людей было довольно тесным, периодически они виделись друг с другом, а также хорошо сохранилась их переписка. В письмах писатель очень почтительно и нежно обращался к другу «дорогой мой Вали-хан», как например, в знаменитом письме Ф.М. Достоевского к Валиханову от 14 декабря 1856 года (ДОСТОЕВСКИЙ 1985: 248-250).

Отлично знавший сибирское общество Чокан Валиханов познакомил писателя с местной интеллигенцией. Например, когда семьи приятеля $\Phi$. Достоевского Ивановых уже не было в Омске, Чокан Валиханов оставался одним из звеньев, связующих Федора Михайловича с кругом декабристов. Молодой Валиханов был своим и в другом омском доме...Речь идет о доме старшей сестры известного русского химика, автора небезызвестной периодической таблицы элементов Д.И. Менделеева, Екатерины Ивановны, в замужестве - Капустиной (ГРОМЫКО 1985: 153). Летом 1859 года Чокан Валиханов ввел в дом Капустиных Федора Достоевского (ГРОМЫКО 1985: 155).

По определению другого нашего земляка и известного этнографа Г.Н. Потанина, в доме у Капустиных собиралась «лучшая омская молодежь», (ГРОМЫКО 1985: 154).

Последняя семипалатинская встреча друзей состоялась в апреле 1859го. По пути из города Верного (современный Алматы) в Омск Ч. Валиханов бывал постоянным гостем в домике на Крепостной улице, где жил Ф. Достоевский (КОСЕНКО 1971: 121).

После недолгого расставания, летом того же года товарищи встречаются уже в Омске. Знаменитый снимок, где они сфотографировались вдвоем, был сделан тогда же (КОСЕНКО 1971: 122124).

Столь тесная дружба объяснялась, разумеется, принадлежностью к единому кругу высокообразованных людей тогдашней Сибири, людей с благородными гражданскими идеалами и честью. На особую симпатию и родство душ, установившиеся между ними, когда Федор Михайлович называл Ч. Валиханова «больше, чем братом», возможно, повлияло и происхождение Ф. Достоевского, его тюркские корни. 
Как следует из источников, одним из далеких предков знаменитого писателя Ф.М. Достоевского был Аслан-Челеби-мурза, выехавший из Золотой Орды в 1389 году с 30 татарами своего знамени к московскому князю Дмитрию Донскому (РОДОСЛОВНЫЕ РАЗВЕДКИ 1912: 284-285).

Крещенный в православии под именем Прокопия, фамилию новый подданный получил по названию реки - Иртыш, откуда он пришел. И вдоль которой кочевали родичи-кипчаки. Ертіс (Иртыш), Ертисчи, иртищеи, то есть - пришельцы с Иртыша (РОДОСЛОВНЫЕ РАЗВЕДКИ 1912: 284-285) .

Так на Руси появился старинный род татарских князей Иртищеевых, давших в одной из своих ветвей боярскую фамилию Ртищевых. (O ПРОИСХОЖДЕНИИ Ф.М. ДОСТОЕВСКОГО).

Родоначальником древнего рода считается сын Прокопия Лев Ртищев (то есть, сын Аслана-Челеби мурзы). За долгую и добрую службу представители этой фамилии не раз получали от государей поместья и звания. (О ПРОИСХОЖДЕНИИ Ф.М. ДОСТОЕВСКОГО)

Согласно источникам, в 1506 году один из его потомков, Данила Иванович Ртищев (Ртищевич, Иртищ, Иртищевич, Артищевич) получил от пинского князя Федора Ивановича Ярославича жалованную грамоту на имение Полкотичи и на часть села Достоева в Пинском повете (уезд), к северо-востоку от Пинска (современная Беларусь). После этого он, его сыновья Иван и Семен Даниловичи и их потомки стали носить фамилию Достоевских.

В 1572 году второй сын Ивана Даниловича, Федор Иванович Достоевский, землевладелец Пинского уезда, поселяется на Волыни вместе с князем А.М. Курбским, который называет его своим "уполномоченным приятелем" (польский юридический термин должности) (ЛЕТОПИСЬ ЖИЗНИ 1993). С XVII века в Литве, в Минской области, в районе Пинских болот находилось имение шляхетской фамилии Достоевских Dostojewo, принадлежавшее польскому гербу Радван.

Потомство прародителя, этого первого Федора Ивановича Достоевского утвердилось на Волыни и положило начало той ветви Достоевских, поселившихся в соседней Подолии, из которой вышел и знаменитый писатель Ф.М. Достоевский (ХРОНИКА РОДА ДОСТОЕВСКОГО 1933).

Многочисленные потомки знатного татарского рода Ртищевых в течение всей его истории имели высокие государственные чины и были приближенными русских правителей.

Так, Михаил Алексеевич Ртищев был воеводой, и при царе Алексее Михайловиче был пожалован в постельничие и окольничие, управлял приказом новой чети (1651-1654).

Его сын, Федор Михайлович большой был окольничим, а Федор Михайлович меньшой - чашником и стольником (в 1663 г.). 
Другой представитель семьи Григорий Иванович Ртищев в 1671 г. был думным дворянином.

Генерал от инфантерии Николай Федорович Ртищев (в 1835 г.) был сенатором, в 1811-1813 гг. управлял Кавказской и Астраханской губерниями и был главнокомандующим в Грузии (ХРОНИКА РОДА ДОСТОЕВСКОГО 1933).

Бояре, сохранившие принадлежность к древней «Иртышской» фамилии, и сами создавали новую топонимику, были весьма известны на Руси. Так, уже упомянутый окольничий царя Алексея Михайловича, в 1666 году боярин Федор Михайлович Ртищев (1626-1673) основал в междуречье хопёрских притоков Ольшанки и Изнаира, на берегу речки Ольшанки село Покровское, получившее в 1723 году название по фамилии владевших им бояр Ртищевых (ХРОНИКА РОДА ДОСТОЕВСКОГО 1933).

Это село Ртищево входило в состав Сердобского уезда сначала Казанской, затем - Астраханской губерний, а с 1780 года - Саратовского наместничества (с 1797 года - Саратовской губернии).

В 1870-1871 годах в полутора верстах южнее села Ртищево пролегла железная дорога Тамбов-Саратов. Вскоре возник пристанционный поселок, который после постройки в 1891-1895 годах новой ветки РязаноУральской железной дороги (РУжд) стал крупный сортировочным узловым пунктом РУжд.

На этой станции Ртищево еще в 1899 году, впервые в России, была построена сортировочная горка.

В 1920 году железнодорожная станция Ртищево получила статус города, который, при создании в 1928 году Нижневолжского края, стал центром Ртищевского района Балашовского округа.

В новейшее время, в 1997 году было создано объединенное муниципальное образование Ртищевского района, включавшее в себя город Ртищево и 96 сельских населенных пунктов.

Интересно, что и в настоящее время, символизируя историческую преемственность, герб города Ртищева и Ртищевского района Саратовской губернии Российской Федерации сохраняет связь с фамильным гербом его основателей.

Общеизвестно, что дворянский герб на Руси есть символ знатной фамилии и их имений. Таковым протяжении сотен лет был и герб рода Ртищевых.

Древние тюрко-мусульманские корни и боярская родословная предков Федора Михайловича Достоевского отражены в содержании фамильного герба Ртищевых. 


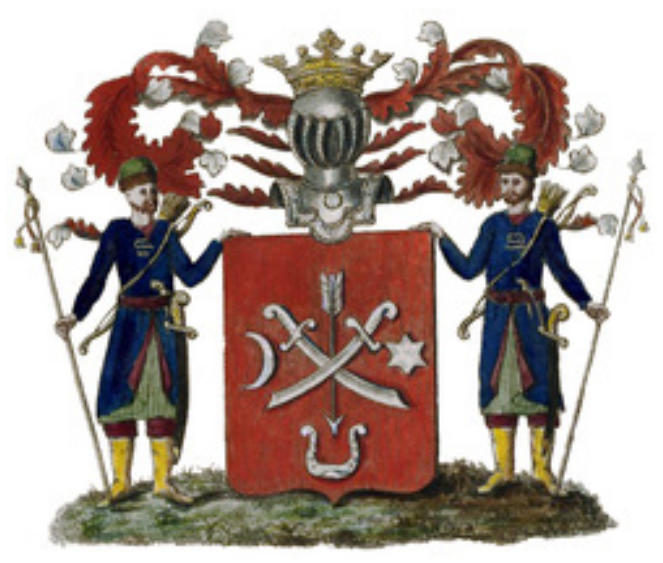

На щите, имеющим красное поле, между Полумесяцем и шестиконечной звездой, изображены две серебряные скрещенные сабли и стрела, летящая вниз к серебряной подкове, обращённой шипами вверх. Щит увенчан дворянским шлемом с дворянской на нём короной. Намёт щита красный, подложен серебром. Щит держат два вооружённых татарина (ОБЩИЙ ГЕРБОВНИК). После распада СССР в России начали восстанавливать старинную геральдику. Тогда же был разработан герб Ртищевского района, принятый 1 августа 2001 года решением N 8-57 Собрания объединенного муниципального образования Ртищевского района и внесенный в Государственный геральдический регистр Российской Федерации под № 789 с официальным описанием:

"В зелёном поле две серебряные сабли накрест и поверх них стрела того же металла, остриями вниз, и вокруг них свитый серебряный и чёрный шнур, уложенный в ичикамор и накрытый в оконечности опрокинутой серебряной подковой".

То есть, на современном гербе города сохранены некоторые элементы, а именно сабли, стрела и подкова, из герба рода Ртищевых (ОБЩИЙ ГЕРБОВНИК).

Интересно, что, оказавшись на Иртыше, Федор Михайлович Достоевский постоянно вспоминал об этом и даже занимался поисками генеалогического характера, не скрывал от местных друзей своего горячего желания изучить те факты, которые могли ему предоставить степняки.

Сохранились свидетельства подобных поисков. Во время поездки Ф. Достоевского в Павлодарский уезд, в ожидании смены почтовых лошадей, он нанял казахскую подводу и поехал по проселку через правобережную полосу пахотных земель. За день добравшись до большого пресного озера Маралды, Ф.М. Достоевский посетил аулы, расположенные поблизости от озера. Там у него состоялись беседы с аксакалами. Поглядывая в свои записи, он задавал вопросы, и 
старейшины объясняли приезжему все хитросплетения степных родословных отношений...». Как знать, возможно, не только писательский интерес, но и некое ощущение космической связи с теми его далекими предками, обитателями кипчакских земель на берегах Иртыша, вели его в казахской степи.

По окончании срока службы Достоевский уезжает в Россию. Известен приказ от 29 апреля 1859 года за №46, где говориться: «Высочайшим его императорского величества приказом, последовавшим в 18 день марта, увольняется от службы Сибирского линейного батальона №7 прапорщик Достоевский, за болезнью, подпоручиком». Летом 1859 года, Федору Достоевскому был выдан временный билет на проезд до г. Твери. Так завершилось пребывание выдающегося русского писателя Федора Михайловича Достоевского на казахской земле.

Несмотря на то, что самые знаменитые произведения Ф.М. Достоевский написал позже, все же представляется, что казахский период его жизни был весьма важен для творчества.

Переходное время, творческий кризис, «второе начало» - так обычно характеризуют сибирский период творчества писателя Достоевского.... Но справедливо подчеркнуть и другое, может быть самое главное. «Дядюшкин сон», «Село Степанчиково.», начало «Мертвого дома», замыслы романов, повестей, рассказов, публицистических статей, процесс интенсивной переоценки ценностей - это все сибирский период творчества Ф.М. Достоевского, составившего в это время величественную программу деятельности на десятилетия вперед (ТУНИМАНОВ 1980: 66).

«Мнение о жизни Федора Михайловича в Омске и Семипалатинске, как не заслуживающей большого внимания, опровергнуто, в сущности, уже самим Достоевским, неоднократно писавшем о формировании важных литературных замыслов в это время. (ГРОМЫКО 1985: 3) Установлено, что за эти пять лет в Семипалатинске были написаны: «Село Степанчиково и его обитатели» и «Дядюшкин сон». Здесь же обдумывались «Записки из Мертвого дома». К концу 1855 - началу 1856 года относятся первые наброски книги (Записки из Мертвого дома-С.Б.), у которой еще нет ни названия, ни плана. Они не сохранились и известны только по письму к поэту А.Н. Майкову... (ТУНИМАНОВ 1980: 68).

Особенный интерес представляет для нас восприятие Ф. Достоевским степного региона, его жителей, какое отражение оно нашло в творчестве писателя.

Во-первых, в письмах Ф.М. Достоевского удивительна почтительная заглавная буква в слове Степь.

Во-вторых, о Степи и ее обитателях он трижды говорит в своих произведениях. Впервые - в «Записках из Мертвого дома»: «...сморишь, бывало, в этот необъятный пустынный простор...все для меня было тут мило: и яркое горячее солнце на бездонном синем небе, и далекая песня киргиза...». 
В хрестоматийном романе «Преступление и наказание» - «с высокого берега открывалась широкая окрестность... Там, в облитой солнцем необозримой степи...там была свобода....

Наконец, в романе «Игрок» вспоминает о Степи «...А я лучше захочу всю жить прокочевать в киргизской палатке, ...чем поклоняться немецкому идолу. Какому идолу? Немецкому способу накопления богатств...» (КОСЕНКО 1971: 61-62).

В-третьих, пять лет пребывания Ф.М. Достоевского на казахской земле - это время позитивных перемен. В период с 1854 по 1859 годы многое в жизни Ф. Достоевского происходит впервые:

1. он превратился из арестанта в вольного человека,

2. дважды был повышен в воинском звании: от солдата до прапорщика и подпоручика перед отставкой,

3. ему было позволено не жить в казарме, а снимать жилье,

4. ему вернули дворянское достоинство,

5. он женился на любимой женщине и обрел семью,

6. научился скакать на лошади.

B-четвертых, не менее значимыми для будущих литературных успехов были растущая внутренняя раскованность и вызревание литературного дара. В Семипалатинске, на берегах Иртыша, Ф.М. Достоевский

1.подружился с Чоканом Валихановым,

2. узнал о жизни Степи и казахов,

3. написал известные повести «Село Степанчиково», «Дядюшкин сон»,

4. задумал и начал писать «Записки из Мертвого дома»,

5.начал активную переписку с издателями его трудов.

Много позже, вспоминая об этом отрезке жизни, он напишет: «Я был очень счастлив» (ДОСТОЕВСКИЙ 1985: 201).

В современном Казахстане весьма почитают творчество Федора Михайловича Достоевского. Центром памяти великого писателя является целый музейный комплекс, расположенный в доме, где жил писатель, естественно, на улице Ф.М. Достоевского в современном городе Семей.

Среди музеев мира, посвященных великому русскому писателю, казахский музей на Иртышских берегах признан уникальным и наиболее полным. Он открылся даже раньше, чем в его родном Петербурге и является единственным «зарубежным» музеем великого писателя.

\section{Литература}

ВОЛГИН 1991 = ВОЛГИН И.Л. Родиться в России... Достоевский и современники: жизнь в документах. М.: Книга, 1991.

ВОЛОЦКОЙ 1933 = ВОЛОЦКОЙ М.В. Хроника рода Достоевского. М., 1933. (47) Ртищевы // Энциклопедический словарь Брокгауза и Ефрона: В 86 томах (82 т. и 4 доп.). СПб., 1890-1907. 
ГРОМЫКО 1985 = ГРОМЫКО М.М. Сибирские знакомые и друзья Ф.М. Достоевского. Новосибирск: Наука, 1985.

ГУРАЛЬНИК 1972 = ГУРАЛЬНИК У.А. Достоевский, славянофилы и «почвенничество» // Достоевский - художник и мыслитель. Сборник статей. М.: Художественная литература, 1972.

ЗУЛХАРОВ $1997=$ ЗҰЛХАРОВ Г. Аягөзге Достоевскийден келген хат. (Электронный ресурс) Режим доступа: http://archive.turkystan.kz/page.php?page id=39\&id=5097

ДОСТОЕВСКИЙ 1985 = ДОСТОЕВСКИЙ Ф.М. Полное собрание сочинений. Т.28. Письма 1832-1859. Л.: Наука, 1985.

КОСЕНКО 1971 = КОСЕНКО П. Иртыш и Нева. Алма-Ата: Жазушы, 1971.

ЛЕТОПИСЬ ЖИЗНИ 1993 = Летопись жизни и творчества Ф.М. Достоевского. Т. 1. СПб, 1993.

ОБЩИЙ ГЕРБОВНИК = Общий гербовник дворянских родов Российской империи. Ч. 3. http://heraldicum.ru/russia/subjects/towns/rtisevo.htm

О ПРОИСХОЖДЕНИИ Ф.М. ДОСТОЕВСКОГО = О происхождении Ф.М. Достоевского (из родословной семьи) // http://genealogia.baltwillinfo.com/genealogy-dostojevsky.htm

РОДОСЛОВНЫЕ РАЗВЕДКИ 1912 = Родословные разведки. Т.1. СПб., 1912.

ТУНИМАНОВ 1980 = ТУНИМАНОВ В.А. Творчество Достоевского 1854-1862. Ленинград: Наука, 1980. 